\title{
India's China strategy under Modi continuity in the management of an asymmetric rivalry
}

\author{
Manjeet S. Pardesi ${ }^{1}$
}

Accepted: 3 February 2021 / Published online: 2 March 2021

(c) The Author(s), under exclusive licence to Springer Nature Limited part of Springer Nature 2021

\begin{abstract}
India's strategy toward China under Modi needs to be understood as the approach of a rising power (in Asia) that has been in relative decline vis-à-vis China. Consequently, Modi's India has adopted a mixed strategy toward its asymmetric rival China that includes accommodation/cooperation at the multilateral level (e.g., the Asian Infrastructure Investment Bank), competition at the regional level (in the Indo-Pacific), rejection of China's unilateral initiatives (such as the Belt and Road Initiative), and deterrence (along the Himalayas and in the Indian Ocean). This seemingly inchoate issue-based approach is function of material and ideational factors. In addition to safeguarding its sovereignty and territorial integrity, India aims to prevent Chinese hegemony in Asia while creating strategic space for itself as a great power in a multipolar Asia. However, India lacks a viable strategy to compete/ catch-up with China economically, and therefore India's overall response will be a constant challenge for its diplomacy.
\end{abstract}

Keywords China $\cdot$ India $\cdot$ Rivalry $\cdot$ Asymmetry

\section{Introduction}

India's strategy toward China over the past few years seems inchoate. India's approach toward the China-led Asian Infrastructure Investment Bank (AIIB) has been accommodationist/cooperative as India is one of its founding members. However, India has rejected China's flagship foreign policy project, the Belt and Road Initiative (BRI). In fact, India seems to be competing with China alongside the USA, Japan, Australia, and others in the wider Indo-Pacific region. Furthermore, India is also in the process of upgrading its conventional military strategy vis-à-vis China in the Himalayas from defense to deterrence. I argue that this variation in India's issuebased response to a rising China is a function of material and ideational factors.

\section{Manjeet S. Pardesi}

manjeet.pardesi@vuw.ac.nz

1 International Relations At Victoria University of Wellington, Wellington, New Zealand 
While this mix of accommodation/cooperation, rejection, competition, and deterrence may superficially seem ad hoc and reactive, India's approach is best understood as the response of an "asymmetric rival" which is itself a rising power in Asia, albeit one that has been in relative decline vis-à-vis China.

In addition to safeguarding its sovereignty and territorial integrity, India aims to prevent Chinese hegemony in Asia while creating the strategic space for itself as a great power in a multipolar Asia. However, even as India has been able to "manage" its rivalry with China thus far, New Delhi lacks a viable strategy to economically catch-up (and compete) with China. Therefore, India's search for suitable options to respond to a powerful China may generate new sources of friction in the Sino-Indian rivalry in the years ahead.

It is now well-established in the literature that Prime Minister Narendra Modi's foreign policy strategy shows all the hallmarks of continuity and gradual evolution of the foreign policy approaches of the previous governments of India. ${ }^{1}$ According to Ganguly (2017: 140), even as Modi has "brought renewed energy to India's foreign policy," the country's approach to the outside world has "not constituted a fundamental break from India's past policies.” Similarly, Basrur (2017: 7) has argued that there has been "no substantive change" in Indian foreign policy under Modi, and that "India's future direction is likely to remain both predictable and moderate." Similarly, Hall's (2019: 7) book-length study concludes that "Modi's government did less to change the direction of Indian foreign policy, its foundational assumptions and key practices, than might be suggested by all the drama and noise it generated." Analogous to the continuity in India's foreign policy in general, the transformation of India's "Look East" strategy to "Act East" strategy under Modi also shows consistency with the policy of the previous governments (Pardesi 2019a, b). Finally, this seems to be true of Modi's foreign policy toward China too, and Madan (2020: 3) has argued that "there has been more continuity than change in the Indian view of and approach toward China since 2008."

I build on this theme of "consistency" to show that India's strategy toward China under Modi (2014 - present) is a continuation of the policies of the previous governments. The causes of the Sino-Indian rivalry are rooted in structural factors: their simultaneous quest for great power status and overlapping spheres of influence in Asia; the status of Tibet and the presence of the Dalai Lama, the Tibetan government-in-exile, and tens of thousands of Tibetan exiles in India; a border dispute that involves significant chunks of territory; the China-Pakistan entente; and India's growing partnerships with the USA as well as Japan and others in East Asia (Garver 2001). However, the Sino-Indian rivalry is asymmetric as India thinks of China as its most consequential rival (and a far greater challenge than Pakistan), even as India is ranked lower than the USA or Japan in the list of China's rivals (Pardesi 2019b; Paul 2018a, b).

In recent decades, successive Indian governments have tried to respond to this asymmetry through a mix of internal balancing, limited external balancing, cooperation/accommodation, and competition depending upon the issue under contention.

\footnotetext{
1 Narendra Modi became the Prime Minister of India in 2014 and was re-elected in 2019.
} 
The two Modi governments have continued with this complex mix of policies with the ultimate aim of supporting India's own rise in a multipolar world while avoiding an overt and militarized conflict with China. Since this rivalry is unlikely to be terminated in the short-to-medium term, the aim is to maintain the Sino-Indian relationship as a "managed rivalry" (Paul 2018a, b: 6). ${ }^{2}$

The rest of this article is divided into six sections. The first section discusses Indian and Chinese views of the international order in Asia and their conceptual approaches toward each other. The second section focuses on the Tibet factor in the Sino-Indian relationship. Border management and military modernization is the focus of the third section. China and India's competition in the wider Indo-Pacific, especially the China-Pakistan and US-India relationships, is the focus of the subsequent section. Trade, connectivity, and international institutions as potential sources of rivalry mitigation are discussed in the fifth section. All of these sections emphasize continuity in Modi's approach toward China with that of the previous Indian governments. The paper concludes by noting factors that may further intensify this rivalry in the coming years.

\section{Worldviews and mutual perceptions}

India has aspired to great power status ever since its independence and emergence as a modern state (Cohen 2002; Nayar and Paul 2002). While the Indian elites' reading of India's history and its civilizational influence in Asia are at the core of this Indian worldview, this quest is also rooted in the beliefs about India's actual and latent material power that ultimately depends on the strength of the Indian economy. According to the then Prime Minister Manmohan Singh (2005a), India's foreign policy "is shaped by our yearning to recover our lost space in the global economy and our economic status in the comity of Nations." A few months later, Singh (2005b) noted the Cambridge historian Angus Madison's "painstaking statistical work" which showed that "India's share of world income collapsed from $22.6 \%$ in 1700 , almost equal to Europe's share of $23.3 \%$ at that time, to as low as $3.8 \%$ in 1952," as a consequence of British colonialism (even as he observed that the Indo-British relationship was "relaxed" and "benign" after independence). ${ }^{3}$

These themes have continued under the Modi governments. According to Subrahmanyam Jaishankar (2019a), India's current foreign minister, the British "took out" an estimated "\$45 trillion at today's value" as a consequence of colonialism. Jaishankar was citing the work of the noted Indian economist, Utsa Patnaik (2017). However, Jaishankar (2019a) added that unlike "another country" that uses the phrase "century of humiliation" to describe its relationship with the west, there has been no mobilization "around an anti-Western nationalism" in India. While Jaishankar was clearly referring to China and its discourse of the "century of

\footnotetext{
${ }^{2}$ Whether or not the rivalry can indeed be "managed" will depend on both Indian and Chinese policies and behavior.

3 Also see Madison Historical Statistics 2018.
}

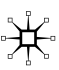


Table 1 China and India's GDP and military expenditure (in current US\$)

\begin{tabular}{llllll}
\hline & \multicolumn{2}{l}{ China } & & \multicolumn{2}{l}{ India } \\
\cline { 2 - 3 } \cline { 5 - 6 } & 1991 & 2018 & & 1991 & 2018 \\
\hline GDP & $\$ 383.4$ billion & $\$ 13.61$ trillion & & $\$ 270.1$ billion & $\$ 2.72$ trillion \\
$\begin{array}{l}\text { Military } \\
\text { expenditure }\end{array}$ & $\$ 9.95$ billion & $\$ 261.1$ billion (2019) & & $\$ 8.62$ billion & $\$ 71.1$ billion (2019) \\
\hline
\end{tabular}

Source For GDP figures, see World Development Indicators, the World Bank, available: https://datac atalog.worldbank.org/dataset/world-development-indicators (accessed: 13 June 2020). For military expenditure figures, see SIPRI military expenditure database, stockholm international peace research institute, available: https://www.sipri.org/databases/milex (accessed: 13 June 2020)

Table 2 China and India's GDP growth rate p.a

\begin{tabular}{lll}
\hline & China (\%) & India $(\%)$ \\
\hline 2014 & 7.3 & 7.4 \\
2015 & 6.9 & 8.0 \\
2016 & 6.7 & 8.2 \\
2017 & 6.8 & 7.2 \\
2018 & 6.6 & 6.8
\end{tabular}

Source World Development Indicators, the World Bank, available: https://datacatalog.worldbank.org/dataset/world-development-indic ators (accessed: 13 June 2020)

humiliation" without actually naming it, it is indeed remarkable that the post-colonial Indo-British relationship is devoid of rivalry or hostility (Pardesi 2021). Jaishankar also expressed confidence that India would emerge as the third-largest global economy in nominal terms by $2030 .^{4}$

Indeed, India has been one of the fastest growing economies since the end of the Cold War, and is currently the fifth-largest global economy in nominal terms (IMF 2019). Consequently, it is not surprising that India is seen as one of the "rising powers" of the emerging world order. However, even as India has "risen" in an absolute sense as well as vis-à-vis almost all countries over the past few decades, India has been in relative decline vis-à-vis China. According to one prominent scholar, India's rise "is occurring in the shadow of China's even more impressive ascent" (Rajagopalan 2017: 1). As shown in Table 1, while there was a rough parity between China and India in terms of the crude indicators of material power at the end of the Cold War in 1991, the Chinese economy is roughly five times the size of the Indian economy today, while China's military expenditure is approximately four times that of India's.

\footnotetext{
${ }^{4}$ In fact, India is already the third-largest global economy when measured at purchasing power parity. See World Bank (2019).
} 
However, Chinese and Indian material power equations are in a flux today. As shown in Table 2, the Indian economy has grown slightly faster than that of China's over the past five years. If this momentum can be maintained, then India has the potential to narrow the material power gap with China in the medium- to long term. ${ }^{5}$ While the past five years coincide with Modi at the helm of India, the country's relatively faster growth rate compared to China is largely a result of the slowdown of the Chinese economy after four decades of high-growth rates as China is seeking to reorient to a domestic consumption-driven economy as opposed to an export-driven economy (due to the structural changes in China's domestic economy as well as the global economy) (Norris 2017). Furthermore, India faces significant structural economic challenges, and the Modi government has been criticized for its economic (mis)management (even before the onset of the COVID-19 pandemic) (Rajan 2020). Nevertheless, if India's much smaller economy can grow relatively faster than China's in the coming years (and decades), then India will be the only major power in the world to "rise" relative to China because the USA and Japan are expected to grow slower than China in the years ahead, and therefore, decline relative to China (Enriquez et al. 2015).

India's leadership remains optimistic about the country's long-term potential. Although Jaishankar (2019b) has acknowledged that India's overall performance compared to China over the past few decades has been "sobering," India's objective remains the creation of a "multi-polar world" with "a multi-polar Asia at its core." Jaishankar (2019b) sees India as one of these poles that plays the role of "a leading power in the future." According to then Foreign Secretary of India, Vijay Gokhale, "all Governments of India" have informed their Chinese counterparts that "both countries [China and India] are emerging as important economies and as important political entities, both the countries are aspirational, not just one. Each country needs to bear that in mind while dealing with the other" (Committee on External Affairs 2018: 3).

In other words, India's "aspiration" to emerge as a great power in Asia and the world has been clearly conveyed to the highest echelons of the Chinese government. Notably, Chinese leaders beginning with President Xi Jinping himself have acknowledged India's aspirations. During his visit to India in 2014, Xi noted that China and India were "two major players in the shaping of a multi-polar world and two vibrant forces driving Asian and global economic growth" (Xi 2014b). Nevertheless, it is widely believed that China's "elites affiliated with the government tend to discount India's potential as a great power" (Pei 2011). The theme of whether or not India will "catch-up" with China is prominent theme in the literature on Sino-Indian relations (Guruswamy and Singh 2009a).

$\mathrm{Pu}(2017:$ 154) argued that the Chinese have "reservations regarding India's great power status," even as they "embrace enthusiastically India's signals of developing country status." According to the noted historian (Wang 2013: Kindle Loc. 1008), China's leaders prefer a "softer" version of "hierarchy" that is rooted in Chinese

\footnotetext{
5 The COVID-19 pandemic is a wild-card and its impact on the power political trajectories of China and India remains unclear.
} 
history. A comparative study of Chinese and Indian strategic cultures led Scobell (2018: 181) to conclude that China does not "see India as a peer or even near-peer competitor," instead, Beijing views New Delhi "more as a spoiler for China's ambitious national goals" that include emerging pre-eminent in Asia. Given the array of contentious issues in the Sino-Indian rivalry and India's own status as a rising power, Westad (2012: 461 emphasis added) predicted that "China's biggest foreign policy challenge in the future will be India," and that "India is a very big challenge" for China because even as "China is well ahead in terms of economic development," India "has its advantages." We now turn to some of the most contentious issues in the Sino-Indian rivalry for an analysis of Modi's policies.

\section{Tibet}

The Tibet factor has been central to the onset of the Sino-Indian rivalry (Pardesi 2019a, b). The Chinese decision to launch a war against India in 1962 was partially rooted in Chinese misperceptions that India wanted to restore Tibet's status as a "buffer state" between India and China (Garver 2006). Following the 1959 Lhasa Uprising (that was the largest revolt against the authority of the Communist Party of China since the founding of the People's Republic of China (PRC) in 1949), the Dalai Lama fled to exile in India followed by tens of thousands of Tibetans. Soon thereafter, he announced the creation of a Tibetan government-in-exile (which is not recognized by any government, including the government of India) (Roemer 2008). In the meanwhile, "as many as half a million Tibetans may have died as a 'direct result' of the policies" of the PRC in the 1950s and 1960s that included a military crackdown, famines (associated with the Great Leap Forward), and other forms of state-backed repression (including the Cultural Revolution) (French 2009: Kindle Loc. 4546).

While India's official position is that the Dalai Lama is an honored guest and that the Tibetan exiles are not allowed to engage in political activities (because India recognizes Tibet as a part of China), New Delhi has implicitly allowed the Tibetans to conduct some political activities. While an incipient process of democratization of this community began in the 1960s, it attained significance in 2001 when almost half of the exiles directly elected the head of the government-in-exile ("Prime Minister" or "President") (Frechette 2007: 112). ${ }^{6}$ The role of the government-in-exile has become more significant since 2011 when the Dalai Lama gave up his political role as the head of this community to the democratically elected Prime Minister/ President (even as he remains the spiritual leader of the Tibetan movement) (Yardley and Wong 2011).

While the Dalai Lama had given up the cause of Tibet's independence in the late 1980s in exchange for genuine political autonomy for Tibet (that included a restricted number of Chinese military installations in Tibet), the Chinese government rejected

\footnotetext{
${ }^{6}$ Since 2017, the title of the "President" is being used to refer to the head of the Tibetan government-inexile (Lobsang 2017).
} 
it as independence in a "disguised form" (Blondeau 2008: 121-123). All talks between the Dalai Lama's representatives and the Chinese government have come to naught and stopped in 2010 (Guardian 2010). Furthermore, China does not recognize the India-based Tibetan government-in-exile, and the Chinese state-controlled media has also referred to Lobsang Sangay, the current President of the exiled government as a "terrorist" (Li 2011). In other words, China is unlikely to talk the representatives of the Tibetan government-in-exile. In the meanwhile, Prime Minister Modi's Bharatiya Janata Party (BJP) had invited Lobsang Sangay to Modi's swearing-in ceremony in 2014 although this courtesy was not extended to him in 2019 (Chaudhury 2019).

The politics of the Tibetans in India has two implications for Sino-Indian relations - the first is related to the status of the Dalai Lama and the Tibetan government-in-exile, while the second is linked to the nature of the Sino-Indian border (which is essentially the Tibet-India border). ${ }^{7}$ The government of Prime Minister Singh began an "annual dialogue" between the Indian foreign secretary and the Dalai Lama in 2004 (Gupta 2014: 215). This dialogue has very likely continued since then even as it is not publicly reported. Given the Dalai Lama's advanced age ${ }^{8}$ the politics of his "reincarnation" will have implications for Sino-Indian relations (Rehman 2019). The Dalai Lama has often described himself as the "son of India," and has even hinted that his next incarnation may be born in India (Handley 2019). However, a Chinese official informed Indian journalists in 2019 that China will "reject" any successor to the Dalai Lama outside China (Laskar 2019). It is noteworthy that the issue of the Dalai Lama's advanced age was discussed between Modi and Xi at their Wuhan Summit in 2017 (Kuronuma 2018). According to one report, they even discussed "informal proposals" in 2015 and 2016 "for India to stop accepting new Tibetan exiles after the death of the Dalai Lama in return for China withdrawing its territorial claim on some parts of northern India” (Kuronuma 2018). The cultural politics of Tibetan Buddhism (and the Dalai Lama) have re-emerged as important factors in the Sino-Indian rivalry (Ranade 2017).

The territories in dispute between India and China are linked to the ambiguous status of Tibet before China's invasion and annexation of Tibet in 1950-51 (Guruswamy and Singh 2009b). After all, it was the Tibetan government that signed the 1913-14 Simla Agreement that marks the border between India and Tibet/China in the eastern sector between Arunachal Pradesh and Tibet today (Lamb 1989). Not surprisingly, the Chinese government rejects this agreement, and since 2006 has been referring to large parts of Arunachal Pradesh as the Chinese territory of Zangnan ("South Tibet") (Garver and Wang 2010: 250).

However, the presence of the Dalai Lama in India, his visits to Arunachal Pradesh (for example, under the Modi government in 2017 (The Hindu 2017)), and his statements that refer to Arunachal Pradesh as a part of India "under the agreement signed

\footnotetext{
7 China's claims on Aksai Chin rest upon Tibet's historical realm, and that region is also a geographical extension of the Tibetan plateau. However, Aksai Chin has been administratively incorporated as a part of Xinjiang (Shichor 2004, 141).

8 The Dalai Lama celebrated his 85th birthday in 2020.
}

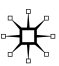


by Tibetan and British representatives" (Times of India 2008), continue to irk China. More recently, in the context of the ongoing militarized tensions along the SinoIndian border in mid-2020, Lobsang Sangay reiterated that Ladakh (in the western sector) "is a part of India" too (Mohan 2020). According to the noted Tibetologist Elliot Sperling, "India's claims to a border that was agreed to by a Tibetan government" in Simla means that the Tibet issue is unlikely to vanish from Sino-Indian relations even after the passing of the current Dalai Lama (Sperling 2012: 232).

The Indian government remains cautious about the Tibet issue given its implications for Sino-Indian relations. In 2018, the Indian government sent a "directive" to senior leaders and government officials asking them to not attend the "Thank You India" events being planned by the Tibetan government-in-exile to commemorate the Dalai Lama's sixty years in India (Financial Express 2018). Similarly, it is not uncommon for some Tibetan activists in India to be arrested during the visits of senior Chinese leaders as happened during Xi's "Chennai Connect" visit in 2019 (The New Indian Express 2019). However, none of these activities suggest any significant change in India's policy toward Tibet. For example, the BJP National General Secretary Ram Madhav, Minister of State for Culture Mahesh Sharma, and BJP member of parliament Shanta Kumar attended the "Thank You India" event (The Tribune 2018). The Tibetans arrested during Xi's visit were also released soon (The Hindu 2019). Similarly, while it has recently been argued that the Modi government scuttled a meeting between Dalai Lama and Xi in 2014, the details remain sketchy, and that it may even be a part of China's strategy to "exploit" the tensions between Indian government and the Dalai Lama (Safi and Kuo 2019). The Indian government understands the salience of Tibet for Sino-Indian relations, including its "intimate links" with the border issue according to a former foreign secretary (Saran 2017: 143).

\section{The border dispute}

According to India, the Sino-Indian border is $3488 \mathrm{~km}$ long. However, China's staterun media has been referring to it as being $2000 \mathrm{~km}$ long (Global Times 2010). It is likely that China's state media does not refer the nearly $1500 \mathrm{~km}$ long border between Kashmir and China's Xinjiang and Tibet regions because Kashmir is disputed between India and Pakistan (and because China has close links with Pakistan as discussed in the next section) (Mohan 2010). In the eastern sector, China claims an area of about 90,000 square kilometers that is more or less co-terminus with the Indian state of Arunachal Pradesh. In the western sector, India claims the Aksai Chin plateau, a region of about 38,000 square kilometers that is under Chinese jurisdiction (as a part of Xinjiang). The middle sector, an area of about 2000 square kilometers that is sandwiched between Aksai Chin and the India-Nepal-Tibet trijunction, 
includes several passes and ancient trading routes where the exact Sino-Indian border remains unclear. ${ }^{9}$

Even as the Sino-Indian border is the world's longest unmarked frontier, it had remained peaceful since 1975 until the 2020 Ladakh Crisis in which twenty Indian soldiers lost their lives (Krishnan 2020). ${ }^{10}$ Although major militarized crises have periodically erupted along this frontier-the 1986-87 Sumdorong Chu crisis, the 2017 Doklam Crisis, and the 2020 Ladakh Crisis - the two sides have thus far prevented the crises from escalating into large-scale hostilities that cause death and destruction (even as low-level fistfights and stone pelting remain common). Nevertheless, India remains concerned about Chinese "transgressions" along the Line of Actual Control (LAC), the de facto border between China and India. For example, the Indian government officially reported 334 transgressions in 2017 (Ministry of Defence 2017-18: 19). By contrast, the Chinese government has never officially released any information regarding what it perceives as India's "violation" of its borders (Fravel 2020: 174).

While it is likely that such violations or transgressions are the result of different perceptions of the LAC, the visits of senior leaders are often associated with large-scale border tensions. For example, the Chinese premier Li Keqiang's 2013 visit to India was associated with a serious incursion as was President Xi's 2014 trip to India. Although the exact reasons behind such border violations remain unclear, India's former foreign secretary Menon has recently argued that such transgressions stem from China's desire "to maintain undisputed military dominance, to convey a clear message to [Indian] civilians and military that they [the Chinese] are the bigger and more powerful party, and to change or create facts on the ground in their [China's] favor" (Menon 2016: 24). India's sense of vulnerability is particularly heightened because China's military budget is now four times larger than India's (as noted in Table 1).

China has been upgrading its military infrastructure in Tibet since the 1980s (Rajagopalan and Prakash 2013). The high-altitude, high-speed railway connecting Qinghai and Tibet that began in 2006 carried troops to Lhasa for the first time in 2007 (BBC News 2007). This railway line was extended to Shigatse (close to the border with India) in 2014 (Economist 2014). Furthermore, China has an extensive road network of almost 97,000 km in Tibet today (Xinhuanet 2019). These road and rail links have been supplemented with at least seven high-altitude airports in Tibet (The Economic Times 2013). In 2016, China reorganized its military commands, and the Western Theater Command that includes the Tibet Military District has approximately 200,000-230,000 ground troops (O’Donnell and Bollfrass 2020: 8). Additionally, at least 157 fighter aircraft are available for operations against India. These troops and platforms are supported by advanced communications and logistics infrastructure.

In turn, India has been seriously trying to address its capability gap with China since 2005, and has been constructing road networks along its Himalayan frontier

\footnotetext{
${ }^{9}$ In addition to this, India also claims the Shaksgam Valley - an area of approximately 5300 square kilometers that has formally been under Chinese jurisdiction since the 1963 Sino-Pakistani agreement Fravel 2008).

${ }^{10}$ The violence of the Ladakh 2020 crisis erupted at the time of this writing and its exact causes remain unclear for now.
} 
and activating a series of airfields (Menon 2016: 24). In 2009, India deployed Su30MKI ground attack aircraft in Assam, and the supersonic BrahMos cruise missiles in Arunachal Pradesh in 2011. In 2013, the government of Prime Minister Singh began the largest peacetime expansion of the Indian armed forces after 1962 by allocating \$15 billion for military modernization to respond to contingencies involving China (Sharma 2013). In particular, Singh's government began raising two mountain divisions $(60,000$ troops) for defensive operations and one mountain strike corps (30,000 troops) for offensive operations against China (Pandit 2014). Although India may enjoy tactical superiority in many contingencies involving China (O'Donnell and Bollfrass 2020: 8-12), overall India seems to be falling behind China (Mastro and Tarapore 2020).

In this context, the most significant change that India has sought in its military response to China along the border is the transformation of its military strategy from defense to (conventional) deterrence (Pardesi 2018; and Rej and Joshi 2018). Notably, the Indian Army has been influenced by the Vietnamese response in the 1979 Sino-Vietnamese War while devising its current approach toward China (Gupta 2014: 226-227). Heretofore, India's security planners had envisaged fighting a defensive war against China in any future conflict (on Indian territory). Consequently, India's frontier regions with China had been purposely left underdeveloped out of the irrational fear that infrastructure upgradation in those regions would end up helping a future Chinese offensive against India. While this strategy of fighting a defensive war might have worked against China in previous decades when SinoIndian power equations were symmetrical, their growing power asymmetry means that this strategy is no longer tenable.

Unlike defense, deterrence implies denying the opponent its battlefield objectives (Mearsheimer 1985). More specifically, India is preparing for two tasks in future contingencies involving China to avoid any territorial loss. The first task involves taking the military offensive behind the Chinese front (whether in India or into China itself at the theater level) in order to interdict Chinese supply lines to prevent any loss of territory (especially in important regions like Tawang in Arunachal Pradesh). While not exactly analogous, India crossed into the territory under Chinese control that was claimed by Bhutan during the 2017 Doklam crisis (Fravel 2020: 175), thereby showing that India was willing to make shallow penetrations into Chinese-controlled territory when Indian (and Bhutanese) interests were at stake. The second task involves the identification and annexation of small chunks of strategically salient points on the Chinese side of the frontier which may then be used as bargaining chips during political negotiations with China to prevent any Chinese political/military presence on the southern slopes of the Himalayas (Khilnani et al. 2012: 41).

It seems like this strategy — of taking the offensive into China at the theater level in order to prevent any territorial loss - that had begun under Prime Minister Singh is being continued under Prime Minister Modi. However, the exact status of the various military modernization projects remains unclear. It was initially suggested that India was shelving the creation of the mountain strike corps in favor of several small rapid reaction forces that would serve as an "interventionist force" due to budgetary reasons (Miglani 2015). However, subsequent reports have argued that India's 
mountain strike corps are being reorganized into "integrated battle groups" to "strike deeper and faster against enemy targets" (The Economic Times 2019). Whatever form these forces ultimately take, India seems to be searching for a financially viable option that will create the possibility of shallow offensives into Chinese-controlled territory as explained above.

Not surprisingly, China has taken a note of these developments. While China remains convinced of its overall military superiority along the Sino-Indian border, the transformation of India's conventional military strategy from defense to deterrence along the Himalayas means that China has begun preparing for a " 1.5 war scenario" with India in the Himalayas in the event of a maritime conflict with the USA or Japan in East Asia. China fears that India may encroach "into the disputed SinoIndian land borders" as it seeks to take advantage of China's military engagement elsewhere (You 2018). ${ }^{11}$ At the same time, China continues to deepen its strategic relations with Pakistan as discussed in the next section. Consequently, India has also begun to plan for a two-front scenario involving China and Pakistan simultaneously (Pardesi 2018) although it is clear that India faces considerable challenges in this regard (Rej 2019). However, these developments demonstrate that the Sino-Indian rivalry is not just a dyadic rivalry ${ }^{12}$; in fact, it is entangled with their relations with Pakistan, the USA, and increasingly Japan.

\section{Competition in the Indo-Pacific}

China-Pakistan relations that had been cordial since the 1950s (despite Pakistan's membership of the US-led South-East Asia Treaty Organization in 1954) became more aligned after the 1962 Sino-Indian War. According to Garver, "Pakistan is arguably the most stable and durable element of China's foreign relations," since the emergence of the PRC (Garver 2001: 187 emphasis original). The China-Pakistan relationship is rooted in multiple factors, including Pakistan's geography at the nexus of South/Central Asia and the Persian Gulf, its role in managing Islamic radicalism in China's Xinjiang (that borders Pakistan), Pakistan's influence in the Muslim-majority states of the greater Middle East, and Pakistan's relations with the superpowers (during the Cold War). However, Pakistan's own rivalry with India has been a central driver of the China-Pakistan partnership. Small (2015: 1) has referred to "Beijing's secretive ties with Islamabad" as "closer than most formal alliances," while Scobell et al. (2018: 129, 142) noted that the China-Pakistan relationship is "quasi-alliance in nature," and is the only partnership referred to by Beijing as an "all weather" strategic partnership.

Indeed, during the 1962 Sino-Indian war, at least half of India's troops were "on the front facing Pakistani troops" (Heimsath and Mansingh 1971: 171). Later, China made overt threats to open a second-front against India during the 1965

\footnotetext{
${ }^{11}$ China is also preparing for another " 1.5 war scenario" with India that will involve a showdown in the Indian Ocean (as opposed to the Himalayas).

12 Tibet's ambiguous historical status means that it was not a dyadic rivalry even when it began.
}

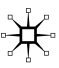


India-Pakistan War, and again contemplated doing so during the 1971 Bangladesh War. India's first nuclear test in 1974 resulted in Chinese nuclear and missile proliferation to Pakistan that included the design of a nuclear weapon (Paul 2003). Later, during the opening of the Karakoram Highway connecting China and Pakistan in 1979, China's Deputy Prime Minister Li Xiannian noted that the highway allowed China "to give military aid to Pakistan" (Topping 1979). China has continued to use Pakistan to prevent any putative Indian hegemony in the subcontinent.

This relationship has continued to flourish even after the end of the Cold War. The Indian leadership noted that during the 1999 Kargil War, China made threatening moves along the Sino-Indian border, while the director of the Department of Armament of the People's Liberation Army also visited Islamabad (Malik 2007: 298). Pakistan accounted for $42 \%$ of China's arms sales during 2002-2014 (Scobell et al.: 138), and 35\% during 2015-19 (SIPRI 2019: 2), making it the largest recipient of Chinese weapons over the past two decades. Notably, China delivered the first batch of the JF-17 fighter jets to Pakistan in 2007, and its overhauled variants in 2019 (Hindustan Times 2019). In the meanwhile, strong political commitments have also continued. In 2019, General Xu Qiliang, Vice Chairman of the Central Military Commission of China described China and Pakistan as "unique all-weather strategic partners and iron brothers," who will "improve defense cooperation, so as to jointly safeguard regional stability," thereby implying the maintenance of a balance of power between India and Pakistan (Ministry of National Defense 2019).

China's footprint in Pakistan has further expanded through the China-Pakistan Economic Corridor (CPEC) project of the BRI that aims to connect Pakistan's Gwadar port at the mouth of the Persian Gulf with Kashgar in Xinjiang by road, rail, and energy pipelines (Jacob 2017). China has officially committed anywhere between \$46-62 billion for this "flagship project" of the BRI that has the potential to transform the Pakistani economy (Bonni 2019: 5). Even before the formal announcement of the BRI/CPEC, India was concerned about the potential presence of Chinese troops in Pakistani-Kashmir, including those engaged in infrastructure building along the border with Xinjiang (Harrison 2010). These concerns have only heightened since then. It is now known that the Pakistani army has raised a division of at least 15,000 soldiers with the specific mission of guarding the CPEC, while its navy has also established "Task Force 88" to protect Gwadar (Bonni 2019: 7). While it remains unclear if any active members of the PLA are present in Pakistan (perhaps in an advisory role to secure the CPEC or as engineers to help with sensitive projects), Chinese private security companies are indeed operating in Pakistan (Nouwens 2019). Given that Pakistan shares a border with China only along PakistaniKashmir, and because India claims all of Kashmir, "India's Pakistan problem now is in large part a China problem" according to Menon (2020: 16).

In the meanwhile, India has been in the process of building a closer strategic partnership with the USA since the end of the Cold War (Pant and Joshi 2016). India's desire to forge this relationship has been rooted in multiple factors: the onset of unipolarity after 1991, access to the American market as well as technology and investments to enable India's economic transformation, and as a route to chart closer relations with America's friends and partners in Asia such as Japan and Australia as India seeks to enhance its own status in the region. However, China has also been 
an important factor promoting closer US-India ties. In 2007, Ronen Sen (2007), the Indian Ambassador to the USA stated that "the Pacific facet of the United States" should be "factored into India's Look East policy." The USA reciprocated this sentiment, and the US Secretary of State Hillary Clinton asked India to "Act East" (as opposed to just "Looking East") in 2011 (Kandeval and Scaria 2011). In 2014, Modi "upgraded" India's "Look East" strategy to "Act East" strategy.

The US-India strategic relationship has been qualitatively upgraded in recent years. In 2016, the USA designated India as a "major defense partner" to facilitate the sharing of high technology at par with its closest allies (Gould 2016). The two countries also signed a military logistics pact in 2016 that gives them reciprocal access to each other's military bases for logistics, fuel, and supplies (George 2016). The 2017 National Security Strategy of the USA "welcome[d] India's emergence as a leading power and stronger strategic and defense partner," while further adding that the US will support "India's leadership role in Indian Ocean security and throughout the broader region," in addition to "support[ing] India's growing relationships throughout" the Indo-Pacific (NSS 2017: 46, 47, and 50). The use of the term Indo-Pacific and America's promotion of "India from the periphery of the Asia-Pacific region to the core of Indo-Pacific region," has been noted by some of China's leading scholars of India who now wonder whether India will carry out "selective alliances" with the USA (and others) in a departure from its traditional policy of strategic autonomy (Li 2018: 45-46).

There is no doubt that India is engaging in limited external balancing with the USA due to the large material gap with China (Pant and Saha 2020). However, India does not wish to emerge as a frontline state in any American strategy of containing the rise of China. While India is certainly seeking a closer partnership with the USA, India's aim is not to promote American primacy; instead, India seeks to create a strategic environment that fosters India's own emergence as a great power in a multipolar Asia (Pardesi 2017). Indeed, India's outgoing foreign secretary noted that India wanted a partnership with the USA on "equal" terms (Gokhale 2020).

In consonance with these objectives, India has transformed its relations with America's Asian partners-Japan and Australia-in recent years. Along with the USA, these four countries are now members of the quadrilateral security dialogue (or "the QUAD") that includes regular security consultations on issues of mutual concern in the Indo-Pacific (Harold et al. 2020). At the same time, these four countries also engage at the trilateral and bilateral levels, especially in terms of militaryto-military links. However, the QUAD is not a multilateral security alliance even as it forms a part of India's strategy to balance China in a limited way through the enhancement of India's own capabilities in association with these countries. There are at least three reasons why India remains wary of any formal alliance with the USA (and its Asian partners). 
First, India continues to value its strategic autonomy. ${ }^{13}$ While strategic autonomy does not preclude close cooperation with other countries on issues of mutual concerns, India does not wish to enter into pacts that will automatically involve New Delhi in conflicts between other states. Given its own history, India wishes to retain the ability to make autonomous decisions as and when contingencies arise. Second, India remains worried about the possibility of a "G-2" accommodation between China and the USA. There are structural limits to closer ties between the US and India when it comes to China because India is geographically contiguous with China but America is geographically separated, and because the China-India power differential favors China but the US-China power differential favors America (Grare 2017). Under such circumstances, a US-China grand bargain may leave India isolated. Third, India also worries about a high-tempo rivalry between the USA and China. In fact, President Donald Trump has even threatened to cut-off ties with China due to the COVID-19 pandemic (Lemon 2020). Indeed, as foreign secretary, Gokhale even wondered if bipolarity was the future of Asia (Committee on External Affairs 2017-2018: 150), even as India itself desires multipolarity as noted above. Such a bipolar rivalry will leave India exposed to China given their geographical contiguity. Therefore, India is charting its own path toward China that includes elements of cooperation.

\section{Trade, connectivity, and institutions}

The most cooperative dimension of Sino-Indian relations is bilateral trade, even as it is fraught with contradictions for India's long-term goals vis-à-vis China (Yuan 2016). While Sino-Indian trade was approximately $\$ 100$ million in the late 1980 s, China (including Hong Kong) is currently India's single-largest trading partner, and total trade stood at \$118.06 billion in 2018-2019 (Department of Commerce 2020). However, this trading relationship is asymmetrical as India was China's tenth-largest trade partner in 2018 (World Integrated Trade Solution 2020). Furthermore, the trade relationship is skewed in China's favor as India's total trade deficit vis-à-vis mainland China was $\$ 53.4$ billion in 2018-2019 and \$4.99 billion with Hong Kong. The asymmetry is even more pronounced as India has been largely exporting raw materials such as minerals, organic chemicals, and cotton to China even as India's imports from the mainland include manufactured goods like machinery, steel, and textiles. India's commercial complaints against China include restrictions on market access in key areas like pharmaceuticals and information technology services where India has a comparative advantage.

This asymmetric commercial relationship is an important reason behind India's nonparticipation in the pan-Asian Regional Comprehensive Economic Partnership (Sen 2019). While Chinese investments in India are certainly rising, New Delhi is unhappy that China is exporting "projects" to India that rely on Indian capital instead of "bringing its own capital to India" (Committee on External Affairs 2017-2018: 46). While

\footnotetext{
${ }^{13}$ Even as American and Indian interests are congruent on issues related to the Indo-Pacific, they diverge on others such as Pakistan, Afghanistan, Iran, and Russia.

On the theoretical distinction between balancing as foreign policy behavior and balance of power as a systemic outcome, see (Kaufman et al. 2007).
} 
cumulative Chinese investments in India stood at $\$ 5$ billion, the value of Indian projects being executed by Chinese companies stood at $\$ 63$ billion. As a result of both economic and political reasons, their unequal economic relationship is unlikely to become balanced anytime soon. Despite Modi's "Make in India" initiative, the country's industrial capacity remains underdeveloped vis-à-vis China (Taneja 2020). More recently, India has imposed restrictions on foreign investment to limit Chinese companies from buying-up Indian firms as a result of the economic stress generated by the COVID-19 pandemic (Parkin 2020). The structural asymmetry in their economic relationship has led Garver to conclude that given the close links between manufacturing, high-technology, and military power, India will continue to lag behind China (Garver 2012).

However, as China's rise continues, India seems ready to cooperate with China wherever appropriate (Panda 2019). India is a founding member of the China-led AIIB, where it is the second-largest stakeholder and has the second-highest voting share. India also remains the AIIB's biggest borrower (Iwanek 2019). Similarly, India is a founder of the New Development Bank (NDB) of the BRICS (Brazil, Russia, India, China, and South Africa) grouping of rising powers. While each member initially contributed $\$ 10$ billion to the NDB, China's contribution in the BRICS Contingent Reserve Fund is \$41 billion compared to India's \$18 billion (Feng 2018: 236-238). China and India's cooperation at the AIIB is related to the "democratization" of the structures of global governance beyond the Western powers that have traditionally dominated such institutions like the World Bank and the International Monetary Fund (as well as their agenda). Furthermore, there is a limited degree of functional cooperation between China and India on security issues such as terrorism as well. India became a full-member of the China-led Shanghai Cooperation Organization in 2017 (Bhattacherjee 2017).

In spite of functional cooperation on select issues, Chinese and Indian interests often diverge in international institutions. For example, China has been blocking India's entry into the Nuclear Suppliers Group (NSG) since India is not a member of the nuclear non-proliferation treaty (NPT). Similarly, China resisted blacklisting Masood Azhar, the leader of the Pakistan-based Jaish-e-Mohammed terrorist organization (linked to the 2001 attacks on the Indian Parliament and the 2008 terror attacks in Mumbai) at the United Nations, arguably at Pakistan's behest, before finally doing so in 2019 as a result of Indian and global pressure (Zheng 2019).

In turn, India has also rejected the China-led BRI (Malik 2019). Notably, India has boycotted both the BRI forums (2017 and 2019) to date. There are two main reasons behind India's rejection of the BRI. First, the flagship project of the BRI, the CPEC, passes through Pakistani-Kashmir. New Delhi is of the opinion that this is a violation of India's sovereignty. In fact, this message has been consistently conveyed to China over many years now. Former Indian foreign minister S. M. Krishna had informed his Chinese counterpart Yang Jiechi in 2010 that Kashmir was a "core" issue for India just like Tibet and Taiwan were for China (Bagchi 2010). Second, India believes that the BRI is a geopolitical initiative with the ultimate goal of Chinese hegemony. Indian leaders view the BRI as a China-led initiative that encompasses a number of bilateral agreements with China, unlike the AIIB that was multilateral (and therefore acceptable to New Delhi).

Sri Lanka's handover of its Hambantota port to China on a 99-year lease in 2017 is a notable example of India's suspicions regarding the BRI as New Delhi regards South Asia and the Indian Ocean to be a part of its own sphere of influence (Stacey 
2017). It had not gone unnoticed in India that Xi had personally assured Sri Lanka in 2014 that China supported "the efforts of Sri Lanka to safeguard its national independence, state sovereignty, and territorial integrity," while "resolutely" opposing "any move by any country to interfere in Sri Lanka's internal affairs under any excuse" (Xi 2014b). The lease of the Hambantota port prompted India to buy an "empty" airport near Hambantota in an attempt to pre-empt the use of that port by the Chinese navy to India's disadvantage (Brewster 2018).

As such, India's rejection of the BRI is being accompanied with its own infrastructure and connectivity initiatives (Jacob 2020). These include multiple projects such under India's Neighborhood First Policy, the Trilateral Highway Project (connecting India-Myanmar, and Thailand), and the Chabahar Port with Iran. However, China's much larger financial resources and project management expertise related to infrastructure building means that there is a recognition in India that working with the USA and Japan, on these initiatives "reassures" India's neighbors in South and Southeast Asia according to Jaishankar (Bagchi 2017). In other words, China has undercut India's primacy in its own neighborhood, and New Delhi will need to work with the USA and its Asian partners to boost its position in its home region.

\section{Conclusion}

China and India are locked in a complex rivalry. Under Modi, India has continued with its approach toward China as set by the previous governments that involve a combination of policies depending on the issue under consideration, including selective cooperation, limited balancing, avoiding confrontation, and upgrading military strategy from defense to conventional deterrence along the Himalayas. India's ultimate aim is to enable its own transformation into a great power without inciting a conflict with China. Therefore, India has chosen to avoid provoking China if India's core interests are not at stake. For example, India has not issued any formal statement on China's "concentration camps" in Xinjiang where more than a million Uighurs have been incarcerated. Similarly, despite being the world's largest democracy, India did not join the international community in condemning China's crackdown of democratic protests in Hong Kong or the change in its political status that has removed any meaningful political autonomy.

The argument presented here has parallels with Bajpai's (2017: 69) recent argument that India's approach toward China is now informed by "a cooperation-defection dynamic." However, there are two critical differences between Bajpai's "mixed" strategy argument and the one put forward in this article. First, in terms of "coalition diplomacy," Bajpai (2017: 79) has claimed that "looking ahead," India aims "to enter into partnership with selected regional powers and the United States to contain China." However, as argued in this article, India's aim is not to promote American primacy. Equally importantly, India's worldview is not driven by the quest to create a "balanced" world order either.

If anything, India remains committed to its long-term quest to emerge as a great power in its own right in a multipolar Asia. Whether such a multipolar world should be governed by a balance of power system, a concert of great powers, or other forms 
of bargains with China, the USA, and others, remains unknown for now as India is yet to acquire the attributes of a full-fledged great power. In fact, India's interests may themselves change (or evolve) as India acquires more power. India's current strategy does not preclude selective cooperation with the USA on China. However, a strategy of containment (without room for other issue-specific responses as highlighted here that also include elements of cooperation) will produce a high-tempo rivalry with China while being materially disadvantaged.

This leads to the second difference with Bajpai's argument for whom India's foreign policy approach toward China has radically changed under Modi. However, his leadership-driven argument is different from the largely structural account presented here that is rooted in the (asymmetric) power dynamics between them as well as differences in worldviews. Therefore, I have attempted to show the continuities between the Modi governments and that of the previous governments of India toward China. As such, New Delhi is continuing with its efforts to narrow the material power gap with China. While the Indian economy has clocked-in impressive rates of growth in recent years, India lacks a viable economic strategy to catch-up with China. If this trend continues, then India's policy toward China will continue to be issue-specific (albeit one that will seem inchoate). However, if India does succeed in narrowing the gap with China, then it will further intensify their rivalry as the move toward parity increases friction (Geller 1993). For example, buoyed by theses dynamics, an emergent nuclear rivalry between China and India seems to be already underway (Narang 2018; and Basrur 2019).

As with Bajpai's argument, my conclusion also has some parallels without another important argument put forth by Rajagopalan (2020) according to whom India is pursuing the strategy of "evasive balancing" toward China that mixes balancing and reassurance. However, Rajagopalan (2020: 89) characterizes the aim of reassurance "to demonstrate to Beijing" that India's balancing efforts (internally as well as externally with the USA and Japan) "are not directed at China or designed to contain it." While Rajagopalan is critical of reassurance strategies as they often fail, my emphasis on cooperative elements in India's strategy toward China (such as accommodation in some issue areas and the avoidance of confrontation in others) is not about reassurance; instead, it is about preventing the emergence of a high-tempo strategic rivalry between them as China and India are asymmetric rivals. This asymmetry is not just about differences in their material power in China's favor. It is also rooted in divergent strategic perceptions as India thinks of China as its principal rival even as China ranks India as a lesser rival behind the USA and Japan.

The existence of a strategic rivalry between China and India means that they are structurally locked in a relationship that has some probability of breaking out into militarized hostilities by definition (Colaresi et al. 2007). Consequently, India's strategy is to build partnerships with China's higher ranked rivals (the USA and Japan), thereby augmenting India's own capabilities while simultaneously demonstrating a degree of independence from them (and through the cooperative elements noted above) because India thinks of balancing as a survival mechanism as opposed to balance of power as a systemic outcome. A strategy of balancing as a systemic outcome (through the creation of alliance-like relationships with the USA and Japan) will result in a bipolar Asia led by the USA and China, thus relegating India as a 
secondary power. However, the pursuit of the mixed strategy as explained in this article_-one that approaches balancing as a survival mechanism—will enable India to create the strategic space for itself as a major power in a multipolar Asia in the medium term as India continues with its relatively slow ascent.

In the meanwhile, the Sino-Indian rivalry will periodically lead to the emergence of militarized crises as well as other foreign policy crises until their rivalry is actually terminated. These crises will need to be managed by deft diplomacy on a case-by-case basis as rivalry termination is not on the horizon (Rasler et al. 2013). However, China and India can take some steps to mitigate their rivalry's most deleterious consequences. New Delhi and Beijing need explore ways to psychologically accommodate the legitimate interests of the other side. As a first step, China needs to accommodate India's aspirations and identity as a great power in Asia. Simultaneously, India needs to accept China as a legitimate player in South Asia and the Indian Ocean. To paraphrase Deng (1988), unless China and India are able to coexist peacefully, "there will be no Asian century."

\section{References}

Bagchi, I. 2010. China refuses to accept J \& K as India's core issue. The Economic Times. 16 November. Bagchi, I. 2017. India wary as Japan, US seek quadrilateral with Australia. Times of India. 28 October

Bajpai, K. 2017. Narendra Modi's Pakistan and China policy: Assertive bilateral diplomacy, active coalition diplomacy. International Affairs 93: 1.

Basrur, R. 2017. Modi's Foreign policy fundamentals: A trajectory unchanged. International Affairs 93: 1.

Basrur, R. 2019. India and China: A managed nuclear rivalry. The Washington Quarterly. 42 (3): $151-170$.

BBC News. 2007. Tibet Train Carries China Troops. 1 December.

Bhattacherjee, K. 2017. India, Pakistan become full members of the SCO. The Hindu. 9 June.

Blondeau, A.-M. 2008. How does the Chinese government view the Dalai Lama's 'new proposal on tibet he put forward in Strasbourg, France, in June 1988? In Authenticating tibet: answers to China's 100 questions, ed. A.-M. Blondeau and K. Buffetrille, 121-123. Berkeley: University of California Press.

Bonni, F. 2019. Protecting the belt and road initiative: China's cooperation with Pakistan to secure CPEC. Asia Policy 14: 2.

Brewster, D. 2018. Why India is buying the World's Emptiest Airport. The Lowy Interpreter. 14 July. Available: https://www.lowyinstitute.org/the-interpreter/why-india-buying-world-s-emptiest-airpo rt. Accessed 16 June 2020.

Chaudhury, D. 2019. No invite for Taiwan representative and Tibet's govt in exile. The Economic Times. 30 May.

Cohen, S. 2002. India: Emerging power. Washington, D.C.: Brookings.

Colaresi, M., K. Rasler, and W. Thompson. 2007. Strategic rivalries in world politics: Position space and conflict escalation. Cambridge: Cambridge University Press.

Committee on External Affairs. 2017-18. Sixteenth Lok Sabha, Twenty First Report, Ministry of External Affairs, March.

Committee on External Affairs. 2018. Sino-Indian relations including Doklam, border situation, and cooperation in international organizations. Sixteenth Lok Sabha, September 2018.

Deng, X. 1988. Excerpt from Deng Xiaoping's talk with Rajiv Gandhi, 21 December. Available: https:// cpcchina.chinadaily.com.cn/2010-10/26/content_13918469.htm. Accessed 16 June 2020.

Department of Commerce. 2020. Government of India, available: https://commerce-app.gov.in/eidb/. Accessed 16 June 2020. 
Economist. 2014. Taming the west. 21 June.

Enriquez, L., Smit, S. and Ablett, J. Shifting tides: global economic scenarios for 2015-2025. McKinsey \& Company, 1 September 2015, available: https://www.mckinsey.com/business-functions/strat egy-and-corporate-finance/our-insights/shifting-tides-global-economic-scenarios-for-2015-25\#. Accessed 13 June 2020.

Feng, L. 2018. China-India engagement in institutions: convergence and divergence on global governance reforms. In The China-India rivalry in the globalization era, ed. T.V. Paul, 236-238. Washington, D.C.: Georgetown University Press.

Financial Express 2018. India sends this big message to China; asks officials, leaders to skip Dalai Lama events. 2 March.

Fravel, M.T. 2020. Stability in a secondary strategic direction: China and the border dispute with India after 1962. In Routledge handbook of China-India relations, ed. K. Bajpai, S. Ho, and M. Miller. New York: Routledge.

Fravel, M.T. 2008. Strong borders, secure nation: Cooperation and conflict in China's territorial disputes. Princeton: Princeton University Press.

Frechette, A. 2007. Democracy and democratization among Tibetans in exile. Journal of Asian Studies 66: 1 .

French, P. 2009. Tibet, tibet: A personal history of a lost land. New York: Vintage.

Ganguly, S. 2017. Has Modi truly changed India's foreign policy? The Washington Quarterly. 40 (2): 131-143.

Garver, J., and F.-L. Wang. 2010. China's Anti-encirclement Struggle. Asian Security. 6: 3.

Garver, J. 2001. Protracted contest: Sino-Indian rivalry in the twentieth century. Seattle: University of Washington Press.

Garver, J. 2006. China's decision for war with India in 1962. In New directions in the study of china's foreign policy, ed. A. Johnston and R. Ross, 86-130. Stanford: Stanford University Press.

Garver, J. 2012. The emerging international china-india division of labour and india's quest for status parity and security with China. In Emerging China: Prospects for partnership in Asia, ed. S. Devare, S. Singh, and R. Marwah, 64-97. New Delhi: Routledge.

Geller, D. 1993. Power differentials and War in Rival Dyads. International Studies Quarterly. 37 (2): $173-193$.

George, V. 2016. India, US sign military logistics pact. The Hindu. 2016.

Global Times. 2010. Opportunities more crucial than differences. 14 December.

Gokhale, V. 2020. Democracy India's Greatest Asset, Poses Challenge to China: Ex-Foreign Secy. StratNews Global. 5 March. Available: https://stratnewsglobal.com/democracy-indias-greatest-asset -poses-challenge-to-china-ex-foreign-secy/. Accessed 15 June 2020.

Gould, J. 2016. US Names India 'Major Defense Partner'. Defense News. 7 June.

Grare, F. 2017. India turns east: International engagement and US-China rivalry. London: Hurst.

Guardian. 2010. Tibet sovereignty is off table, China tells Dalai Lama Envoys. 1 February.

Gupta, S. 2014. The Himalayan face-off. Gurgaon: Hachette.

Guruswamy, M., and Z.D. Singh. 2009a. Chasing the Dragon: Will India catch up with China? Delhi: Longman.

Guruswamy, M., and Z.D. Singh. 2009b. India-China relations: The border issue and beyond. Delhi: Viva.

Hall, I. 2019. Modi and the reinvention of Indian foreign policy. Bristol: Bristol University Press.

Handley, E. 2019. Dalai Lama says he could be reincarnated in India, but Beijing says rebirth must follow Chinese rules. ABC News. 21 March. Available: https://www.abc.net.au/news/2019-03-21/dalai -lama-says-he-could-be-reincarnated-in-india/10923354. Accessed on 30 Sep 2019.

Harold, S., Madan, T., and Sambhi, N. 2020. U.S.-Japan Alliance Conference: Regional Perspectives on the Quadrilateral Dialogue and the Free and Open Indo-Pacific. Santa Monica: RAND.

Harrison, S. 2010. China's discreet hold on Pakistan's Northern Borderlands. New York Times. 26 August. Heimsath, C., and S. Mansingh. 1971. A diplomatic history of modern India. Calcutta: Allied Publishers. Hindustan Times. 2019. China delivers first overhauled JF-17 fighter jet to Pakistan. 22 May.

IMF. 2019. World economic outlook database. October. Available: https://www.imf.org/external/pubs/ft/ weo/2019/02/weodata/index.aspx. Accessed 13 June 2020.

Iwanek, K. 2019. Fully invested: India remains the China-led AIIB's biggest borrower. The Diplomat. 6 September.

Jacob, J. 2017. China's belt and road initiative: Perspectives from India. China and World Economy 25 (5): 78-100. 
Jacob, J. 2020. China, India, and Asian connectivity: India's view. In Routledge handbook of China-India relations, ed. K. Bajpai, S. Ho, and M. Miller. New York: Routledge.

Jaishankar, S. 2019a. The Text of S. Jaishankar's US talk on how he sees India's relationship with the West. The Print. 4 October. Available: https://theprint.in/diplomacy/foreign-minister-jaishankar -us-talk-atlantic-council-think-tank-washington-india-relationship-west/300853/. Accessed 13 June 2020.

Jaishankar, S. 2019b. S Jaishankar at RNG Lecture full text. The Indian Express. 16 November.

Kandavel S. and Scaria, J. 2011. Look east, and act east, too: US Secretary of State Hillary Clinton to India. The Economic Times. 20 July.

Kaufman, S., R. Little, and W. Wohlforth, eds. 2007. The balance of power in world history. Basingstoke: Palgrave.

Khilnani, Sunil et al. 2012. Nonalignment 2.0: A foreign and strategic policy for india in the twenty first century. Available: https://www.cprindia.org/research/reports/nonalignment-20-foreign-and-strat egic-policy-india-twenty-first-century. Accessed 14 June 2020.

Krishnan, A. 2020. Forgotten in fog of war, the last firing on the India-China border. The Hindu. 14 June.

Kuronuma, Y. 2018. India uses Rumor of Dalai Lama's Il health to mend China Ties. Nikkei Asian Review. 7 August.

Lamb, A. 1989. Tibet, China and India: A history of imperial diplomacy. Hertfordshire: Roxford.

Laskar, R. China may reject Dalai Lama chosen abroad. Hindustan Times. 16 July.

Lemon, J. 2020. Trump threatens to 'Cut Off Whole Relationship' With China, Says U.S. Would Save $\$ 500$ Billion. Newsweek. 14 May.

Li H. 2011. Terrorist Poised to Rule “Tibetan Government-in-Exile?”.” People's Daily Online. 22 March. Available: http://en.people.cn/90002/96417/7326988.pdf. Accessed 14 June 2020.

Li, L. 2018. The new trend of india's rising as a great power. Contemporary International Relations (March/April).

Lobsang, W. 2017. CTA uses "President" as translation of Sikyong, Tibet Sun. 2 May. Available: https ://www.tibetsun.com/news/2017/05/02/cta-uses-president-as-translation-of-sikyong. Accessed 14 June 2020.

Madan, T. 2020. Managing China: competitive engagement, with indian characteristics, the 'Global China: Assessing China's Growing Role in the World' project of the Brookings Institute. February. Available: https://www.brookings.edu/research/managing-china-competitive-engagement-withindian-characteristics/. Accessed 13 June 2020.

Madison Historical Statistics. 2018. University of Gronigen, updated on 11 January 2018. Available: https://www.rug.nl/ggdc/historicaldevelopment/maddison/. Accessed 13 June 2020.

Malik, A. 2019. India, China, and the BRI. In China ascendant: Its rise and implications, ed. Harsh V. Pant, 86-96. HarperCollins.: New Delhi.

Malik, V. 2007. Kargil: From surprise to victory. New Delhi: HarperCollins.

Mastro, O., and A. Tarapore. 2020. Asymmetric but uneven: The China-India conventional military balance. In Routledge handbook of china-india relations, ed. K. Bajpai, S. Ho, and M. Miller, 240251. New York: Routledge.

Mearsheimer, J. 1985. Conventional deterrence. Ithaca: Cornell University Press.

Menon, S. 2016. Choices: Inside the making of India's foreign policy. Washington, D.C.: Brookings.

Menon, S. 2020. India' Foreign Affairs Strategy. Brookings India, May.

Miglani, S. 2015. India scales back army corps facing China, pours funds into carrier. Reuters. 16 May. Available: https://in.reuters.com/article/india-defence-idINKBN0O01C420150515. Accessed on 14 June 2020.

Ministry of Defence. 2017-18. Annual Report, 2017-18. Available: https://mod.gov.in/sites/default/files/ AR1718.pdf. Accessed 14 June 2020.

Ministry of National Defense. 2019. Defense Ministry's regular press conference on Aug. 29. 29 August. Available online: http://eng.mod.gov.cn/focus/2019-08/29/content_4849335.htm. Accessed 17 Sep 2019.

Mohan, G. 2020. Peaceful Resolution of Tibet Solution to India-China Border Dispute: Tibetan govt-inexile. India Today. 2 June.

Mohan, R. 2010. The mystery of missing thousand miles in J\&K. Indian Express. 19 December.

Narang, V. 2018. Nuclear deterrence in the China-India Dyad. In The China-India rivalry in the globalization era, ed. T.V. Paul, 187-201. Washington, D.C.: Georgetown University Press.

Nayar, B., and T.V. Paul. 2002. India in the world order: Searching for major power status. Cambridge: Cambridge University Press. 
Norris. 2017. Geostrategic implications of China's Twin economic challenges. Discussion Paper, Council on Foreign Relations, June.

Nouwens, M. 2019. China's use of private companies and other actors to secure belt and road across South Asia. Asia Policy 14 (2): 13-20.

NSS. 2017. National security strategy of the United States of America. The White House 46 (47): 50.

O'Donnell, F. and Bollfrass, A. 2020. The strategic postures of China and India: A visual guide. Project on Managing the Atom, Belfer Center for Science and International Affairs, 2020

Panda, J. 2019. Asian equilibrium: India's overture to China. In India and China in Asia: Between equilibrium and equations, ed. Jagannath P. Panda. London: Routledge.

Pandit, R. 2014. Army kicks off raising new mountain strike corps against China. Times of India. 9 January 2014.

Pant, H., and Y. Joshi. 2016. The US Pivot and Indian Foreign Policy: Asia's evolving balance of power. Basingstoke: Palgrave.

Pant, H., and P. Saha. 2020. India, China, and the Indo-Pacific: New Delhi's recalibration is underway. The Washington Quarterly 43 (4): 187-206.

Pardesi, M. 2017. American global primacy and the rise of India. AsiaPacific Issues. No. 129, March 2017.

Pardesi, M. 2018. India's conventional military strategy. In The Oxford handbook of India's national security, ed. S. Ganguly, N. Blarel, and M. Pardesi. New Delhi: Oxford University Press.

Pardesi, M. 2019. The initiation of the Sino-Indian rivalry. Asian Security 15 (3): 253-284.

Pardesi, M. 2021. India and Peaceful Change. In The Oxford Handbook on Peaceful Change in International Relations, ed. T.V. Paul, D. Larson, H. Trinkunas, A. Wivel, and R. Emmers. New York: Oxford University Press. https://doi.org/10.1093/oxfordhb/9780190097356.013.29.

Pardesi, M.S. 2019. Modi: From 'Look East' to 'Act East': Semantic or substantive change? International Studies Perspectives 20 (1): 29-33.

Parkin, B. 2020. India moves to curb Chinese corporate takeovers. Financial Times. 19 April.

Patnaik, U. 2017. Revisiting the 'Drain', or transfers from India to Britain in the context of global diffusion of capitalism. In Agrarian and other histories: Essays for Binay Bhushan Chaudhuri, ed. S. Chakrabarti and U. Patnaik, 277-317. Tulika: New Delhi.

Paul, T. 2003. Chinese-Pakistani nuclear/missile ties and the balance of power. Nonproliferation Review 10 (2): 21-29.

Paul, T.V., ed. 2018. The China-India rivalry in the globalization era. Washington, D.C.: Georgetown University Press.

Paul, T.V. 2018. Explaining conflict and cooperation in the China-India Rivalry. In The China-India rivalry in the globalization era, ed. T.V. Paul. Washington, D.C.: Georgetown University Press.

Pei, M. 2011. Dangerous misperceptions: Chinese views of India's rise. India in Transition. Center for the Advanced Study of India. 23 May. Available online: https://casi.sas.upenn.edu/iit/pei. Accessed Sep 292019.

$\mathrm{Pu}, \mathrm{X}$. 2017. Ambivalent accommodation: Status signalling of a rising India and China's response. International Affairs 93: 1.

Rajagopalan, R. 2017. India's strategic choices: China and the balance of power in Asia, Carnegie India, September. Available online: https://carnegieindia.org/2017/09/14/india-s-strategic-choices-china -and-balance-of-power-in-asia-pub-73118. Accessed 2 Jan 2021.

Rajagopalan, R. 2020. Evasive balancing: India's unviable Indo-Pacific strategy. International Affairs 96 (1): 75-93.

Rajagopalan, R.P., and Prakash, R. 2013. Sino-Indian Border Infrastructure: An Update, ORF Occasional Paper \#42, Observer Research Foundation.

Rajan, R. 2020. 'I'm Worried by the Extent of Economic Catastrophe India is Facing'. The Wire. 27 May.

Ranade, J. 2017. Buddhism: A new frontier in the China-India rivalry. Carnegie India, March. Available online: https://carnegieindia.org/2017/03/17/buddhism-new-frontier-in-china-india-rivalrypub-68326. Accessed 4 Jan 2021).

Rasler, K., W. Thompson, and S. Ganguly. 2013. How rivalries end. Philadelphia: University of Pennsylvania Press.

Rehman, I. 2019. After his holiness: Tibet, reincarnation politics and the future of Sino-Indian relations. Survival 61 (4): 131-156.

Rej, A., and Joshi, S. 2018. India's joint doctrine: A lost opportunity. ORF Occasional Paper 139, Observer Research Foundation. 
Rej, A. 2019. The sobering arithmetic of a two-front war. In China ascendant: Its rise and implications, ed. Harsh V. Pant, 86-96. HarperCollins.: New Delhi.

Roemer, S. 2008. The Tibetan government-in-exile: Politics at large. London: Routledge.

Safi, M. and Kuo, L. 2019. Dalai Lama lets slip how India vetoed his meeting with China's leader in 2014. The Guardian. 19 May.

Saran, S. 2017. How India sees the world: Kautilya to the twenty-first Century. New Delhi: Juggernaut.

Scobell, A. 2018. Himalayan standoff: Strategic culture and the China-India rivalry. In The China-India rivalry in the globalization era, ed. T.V. Paul. Washington, D.C.: Georgetown University Press.

Scobell, A., et al. 2018. At the dawn of belt and road: China in the developing world. Santa Monica: RAND.

Sen, A. 2019. China promises greater market access to India if it improves RCEP offer. The Hindu BusinessLine. 18 July.

Sen, R. 2007. Building strategic Asia: The United States, Japan, and India. Embassy of India (USA), 28 June. Available: https://indianembassyusa.gov.in/ArchivesDetails?id=877. Accessed 15 June 2020.

Sharma, R. 2013. How India is Preparing to Counter the China Threat. First Post.

Shichor, Y. 2004. The great wall of steel: Military and strategy in Xinjiang. In Xinjiang: China's Muslim borderland, ed. S. Frederick Starr. M. E. Sharpe: Armonk.

Singh, Manmohan. 2005a. PM's speech at India today conclave. 25 February. Available: https://archi vepmo.nic.in/drmanmohansingh/content_print.php?nodeid=73\&nodetype=2. Accessed 13 June 2020.

Singh, Manmohan. 2005b. Address by Prime Minister Dr. Manmohan Singh in acceptance of honorary degree from Oxford University." Ministry of External Affairs. 8 July. Available: https://mea. gov.in/Speeches-Statements.htm?dt1/2623/Address+by+Prime+Minister+Dr+Manmohan+Singh +in+acceptance+of+Honorary+Degree+from+Oxford+University. Accessed 13 June 2020.

SIPRI. 2019. Trends in international arms transfers, SIPRI Factsheet, 2. Available: https://www.sipri.org/ sites/default/files/2020-03/fs_2003_at_2019.pdf. Accessed 15 June 2020.

Small, A. 2015. The China-Pakistan axis: Asia's new geopolitics. New York: Oxford University Press.

Sperling, E. 2012. The tibet conundrum in Sino-Indian Ties. In The rise of China: Implications for India, ed. H.V. Pant. New Delhi: Cambridge University Press.

Stacey, K. 2017. China signs 99-year lease on Sri Lanka's Hambantota Port. Financial Times. 11 December.

Taneja, P. 2020. Bilateral economic relations amid trade and trust deficits. In Routledge handbook of China-India relations, ed. K. Bajpai, S. Ho, and M. Miller. New York: Routledge.

The Economic Times. 2013. China to build 7th airport in Tibetan region. 9 September.

The Economic Times. 2019. Indian Army's Mountain Strike Corps, Air Force to carry out war games near China border. 11 September.

The Hindu. 2017. As the Dalai Lama visits Arunachal Pradesh, China vows to take 'Necessary Measures'. 5 April.

The Hindu. 2019. Tibetan poet Tenzin Tsundue released from Puzhal prison. 17 October.

The New Indian Express. 2019. Tibetan Activist Arrested in Tamil Nadu Ahead of Chinese President Xi Jinping's Visit. The New Indian Express. 7 October.

The Tribune. 2018. BJP Leaders Attend Tibetans' 'Thank You India' Event at Dharamsala. 31 March.

Times of India. 2008. Tawang is a part of India: Dalai Lama. 4 June.

Topping, S. 1979. Opening the High Road to China. New York Times. 2 December.

Wang, G. 2013. Renewal: The Chinese state and the new global history, 2013. Hong Kong: The Chinese University of Hong Kong.

Westad, O. 2012. Restless Empire: China and the world since 1750. London: The Bodley Head.

World Bank. 2019. Gross domestic product 2018, PPP. World Development Indicators Database. 23 December. Available: https://databank.worldbank.org/data/download/GDP_PPP.pdf. Accessed 13 June 2020.

World Integrated Trade Solution. 2020. The World Bank, available: https://wits.worldbank.org/. Accessed 16 June 2020.

Xi, J. 2014a. In Joint Pursuit of a Dream of National Renewal.” Ministry of Foreign Affairs. 19 September. Available: https://www.fmprc.gov.cn/mfa_eng/topics_665678/zjpcxshzzcygyslshdsschybdtjkst medfsllkydjxgsfw/t1194300.shtml. Accessed 13 June 2020.

Xi, J. 2014b. Let Us Become Partners in Pursuit of our Dreams. Daily News. 18 September. Available: https://www.mfa.gov.lk/exclusive-xi-jinping-president-peoples-republic-of-china-to-daily-newsreaders-let-us-become-partners-in-pursuit-of-our-dreams/. Accessed 16 June 2020. 
Xinhuanet. 2019. Tibet's highway mileage reaches $97,000 \mathrm{~km}$. 16 January.

Yardley J. and Wong, E. 2011. Dalai Lama Gives Up Political Role. New York Times. 10 March.

You, J. 2018. The Indian Ocean: A grand Sino-Indian game of 'Go'.' In: Brewster, D. (ed.). India and China at Sea: Competition for Naval Dominance in the Indian Ocean. New Delhi: Oxford University Press. DOI:https://doi.org/10.1093/oso/9780199479337.003.0006. Accessed 14 June 2020.

Yuan, J. 2016. Sino-Indian economic ties since 1988: Progress, problems, and prospects for future development. Journal of Current Chinese Affairs. 45 (3): 31-71.

Zheng, S. 2019. Why China dropped its opposition to UN blacklisting of Pakistan-based terror chief Masood Azhar. South China Morning Post. 2 May.

Publisher's Note Springer Nature remains neutral with regard to jurisdictional claims in published maps and institutional affiliations. 